\title{
Application of Immobilized Pointed Gourd (Trichosanthes dioica)Peroxidase- Concanavalin A Complex on Calcium Alginate Pectin Gel in Decolorization of Synthetic Dyes Using Batch Processes and Continuous Two Reactor System
}

\author{
Farrukh Jamal ${ }^{1 *}$, Sangram Singh ${ }^{1}$, Sadiya Khatoon ${ }^{1}$ and Sudhir Mehrotra ${ }^{2}$
}

${ }^{1}$ Department of Biochemistry, Dr. Ram Manohar Lohia Avadh University, Faizabad-224001, U.P, India

${ }^{2}$ Department of Biochemistry, University of Lucknow, Lucknow, U.P, India

\begin{abstract}
Ammonium sulphate fractionated pointed gourd (Trichosanthes dioica) peroxidase- concanavalin A (PGP-Con A) complex was entrapped into calcium alginate-pectin gel. Catalytic performance of immobilized PGP-Con A complex in dye decolorization was examined on repeated use and reusing after a prolonged period of storage. Immobilized and entrapped peroxidase preparation retained $59.6 \%$ of the original activity after a period of $50 \mathrm{~d}$. Entrapped PGPCon A complex decolorized $91.2 \%$ and $82.1 \%$ of the initial color from DR19 and dye mixture [DR19+DB9] after $20 \mathrm{~d}$, respectively. Considerable color removal was found even after $120 \mathrm{~d}$ and $80 \mathrm{~d}$ respectively, of operation of two reactor system and total organic carbon analysis was quite comparable to color loss. This study shows the efficacy, durability and sustainability of using immobilized $T$. dioica peroxidase in batch and continuous two reactor catalytic system for the removal of synthetic dyes from industrial effluents.
\end{abstract}

Keywords: Concanavalin A; Pointed gourd peroxidase (PGP); Immobilization; Biocatalysis; Continuous reactor; Disperse dyes

\section{Abbreviations}

Pointed Gourd Peroxidase- concanavalin A (PGP-Con A); Disperse Red (DR 19); Disperse Black (DB 9); Trichosanthes dioica (T. dioica); Days (d); Weight/volume (w/v); Concanavalin A (Con A); Percent (\%); $\mathrm{U}$ (units); TOC (total organic carbon); $\lambda$ (wavelength); $\mathrm{nm}$ (nanometre)

\section{Introduction}

Enzymes are not only environmental friendly but are also capable of specifically reducing hazardous wastes and hence key to new processes. Due to considerable increase in the level of phenolic compounds and dyes contamination in waste water; approaches that are cheaper, sustainable and eco-friendly are highly desired. Peroxidases are hemecontaining monomeric glycoproteins that oxidize a wide variety of molecules [1,2]. These enzymes find wide range of applications in detoxification, dye decolorization and removal of various toxic organic pollutants which contaminate water and industrial effluents [3-5]. Extensive research has focused on developing processes in which enzymes are employed to remove dyes from polluted water [6-8]. Several factors like shorter treatment period; operation of high and low concentrations of substrates; reduced lag phase of biomass, reduction in sludge volume and ease of controlling the process makes enzymatic treatment potentially useful as compared to microbial treatment. Although these enzymes catalyze a variety of aromatic compounds in the presence of hydrogen peroxide, several limitations prevent the use of liquid form of enzymes as their stability and catalytic ability decreases with the complex nature of the effluents [9]. Some of these limitations may be overcome by the use of immobilized enzymes that can be used as catalysts with long lifetime. Immobilization with different polymeric materials is studied for enzyme encapsulation along with their application in treatment of various pollutants. However, appropriate selection of encapsulation material specific to the enzyme and optimization of process conditions is still in early stage of development [10]. The immobilized form of enzymes has several merits over the soluble enzymes such as enhanced stability, easier product recovery and purification, protection of enzymes against denaturants, proteolysis and reduced susceptibility to contamination [9].
The methodologies employed for the immobilization of peroxidases are limited and among them bioaffinity-based physical adsorption strategy is useful and economical [11]. This process can immobilize enzyme directly from crude homogenate overcoming the high cost of purification which employs commercially available enzyme/expensive supports [12]. Besides conferring ease to immobilize proteins, other advantages of such protocols include lack of chemical modification, proper orientation of enzyme on the support, high yield and enhanced stability of glycoenzymes/enzymes [13].

Novel research in the area of enzyme technology has provided significant evidence and strategies that facilitate using enzymes optimally at large scale by entrapping and immobilizing $[14,15]$ Although enzymes entrapped in porous polymeric matrices pose inherent limitations of enzyme leaching; however by controlling the pore dimensions such leaching can be minimized. Alternatively, entrapping cross-linked or pre-immobilized enzyme preparations could be a better and pragmatic option [16].

Immobilization of enzymes is a tricky and articulated approach with regard to proper orientation, as involvement of key amino acids must be avoided to prevent loss of enzymatic activity. In case of glycoenzymes, glycosyl moieties can safely be used in immobilizations as they do not participate in catalysis. Lectins are proteins which recognize and interact with exposed carbohydrate moieties of glycoproteins and glycoenzymes. These proteins are useful in characterizing glycoproteins

*Corresponding author: Farrukh Jamal, Assistant Professor, Department of Biochemistry, Dr. Ram Manohar Lohia Avadh University, Faizabad-224001, U.P, India, Fax: +91-05278-246330; E-mail: farrukhrmlau@gmail.com; journal.farrukh@gmail.com

Received July 12, 2013; Accepted August 08, 2013; Published August 30, 2013

Citation: Jamal F, Singh S, Khatoon S, Mehrotra S (2013) Application of Immobilized Pointed Gourd (Trichosanthes dioica) Peroxidase-Concanavalin A Complex on Calcium Alginate Pectin Gel in Decolorization of Synthetic Dyes Using Batch Processes and Continuous Two Reactor System. J Bioprocess Biotech 3: 131 doi: $10.4172 / 2155-9821.1000131$

Copyright: (c) 2013 Jamal F, et al. This is an open-access article distributed unde the terms of the Creative Commons Attribution License, which permits unrestricted use, distribution, and reproduction in any medium, provided the original author and source are credited. 
Citation: Jamal F, Singh S, Khatoon S, Mehrotra S (2013) Application of Immobilized Pointed Gourd (Trichosanthes dioica) Peroxidase-Concanavalin A Complex on Calcium Alginate Pectin Gel in Decolorization of Synthetic Dyes Using Batch Processes and Continuous Two Reactor System. J Bioprocess Biotech 3: 131 doi: 10.4172/2155-9821.1000131

Page 2 of 5

and certain glycoenzymes have been immobilized on concanavalin A affinity matrices or as Con A-glycoenzyme complexes [13,17].

The current study demonstrates a simple, inexpensive and high yield procedure for immobilization of glycosylated Trichosanthes dioica peroxidase. T. dioica popularly known as pointed gourd is widely planted in tropical areas and consumed as vegetables. Salt fractionated pointed gourd peroxidase immobilized with lectin Con A as insoluble PGP-Con A were entrapped into calcium alginate-pectin beads. A comparative study on the reusability and storage stability of soluble and immobilized form of PGP (PGP-Con A complex and PGP-Con A-calcium alginate-pectin complex) has been presented for using such enzymes in effectively removing/minimising the color in industrial effluent contaminated with dyes.

\section{Materials and Methods}

\section{Chemicals}

Sodium alginate, Bovine serum albumin (BSA), Concanavalin A, $o$-dianisidine $\mathrm{HCl}$, Disperse Red 19 and Disperse Black 9 was procured from Sigma Chemical Co. (St. Louis, MO, USA). Pectin was obtained from SRL Chemicals, Mumbai, India. All other chemicals were of analytical grade. The pointed gourds were procured from Narendra Dev University of Agriculture and Technology, Faizabad, U.P., India. The samples were aseptically transferred into sterilized plastic bags.

\section{Ammonium sulphate purification of PGP proteins and protein estimation}

The homogenate of pointed gourd ( 300 gm) was homogenized in $600 \mathrm{~mL}$ of $100 \mathrm{mM}$ sodium acetate buffer, $\mathrm{pH}$ 5.6, filtered through multi-layers of cheesecloth and centrifuged at $10,000 \times \mathrm{g}$ on a Remi $\mathrm{C}-24$ cooling centrifuge for $25 \mathrm{~min}$ at $4^{\circ} \mathrm{C}$. The supernatant was salt fractionated by continuously stirring at $4^{\circ} \mathrm{C}$ overnight using $10 \%$ to $80 \%(\mathrm{w} / \mathrm{v})\left(\mathrm{NH}_{4}\right)_{2} \mathrm{SO}_{4}$. The precipitate was centrifuged at $10,000 \times \mathrm{g}$ on a Remi C-24 cooling centrifuge, dissolved in $100 \mathrm{mM}$ sodium acetate buffer, pH 5.6 and dialyzed against the assay buffer $(100 \mathrm{mM}$ glycine $\mathrm{HCl}$ buffer, $\mathrm{pH} 5.6[4,7]$. This preparation of protein was aliquoted and stored at $-20^{\circ} \mathrm{C}$ for further use.

Protein concentration was estimated using BSA as a standard protein and following the procedure of Lowry et al. [18].

\section{Preparation of insoluble PGP-Con A complex and entrapment in calcium alginate-pectin beads}

The peroxidase proteins $(1100 \mathrm{U})$ were mixed with an increasing concentration of Con A (0.1-1.0 mL) in a series of tubes. Final volume of each tube was adjusted to $5 \mathrm{~mL}$ with $100 \mathrm{mM}$ phosphate buffer $(\mathrm{pH}$ 5.6). The reaction mixtures were incubated overnight at $37^{\circ} \mathrm{C}$. The precipitates were collected after centrifugation at 3000xg for $20 \mathrm{~min}$ at room temperature and washed twice with the same buffer. Finally precipitates were suspended in $2 \mathrm{~mL}$ assay buffer and each precipitate was analyzed for enzyme activity. The precipitate (PGP-Con A complex) exhibiting maximum activity was used for further studies.

PGP-Con A complex (1250 U) was mixed with sodium alginate (2.5\%) and pectin (2.5\%) in $10 \mathrm{~mL}$ of $100 \mathrm{mM}$ sodium acetate buffer ( $\mathrm{pH}$ 5.6). Using a syringe the mixture was slowly extruded as droplets. Further, beads were gently stirred for $2 \mathrm{~h}$ in calcium chloride solution $(1.5 \% \mathrm{w} / \mathrm{v})$, washed and stored in $100 \mathrm{mM}$ sodium acetate buffer $(\mathrm{pH}$ 5.6) at $4^{\circ} \mathrm{C}$ for further use $[7,19]$.

\section{Measurement of peroxidase activity and effect of enzyme loading}

Peroxidase activity was determined by measuring a change in optical density $\left(\mathrm{A}_{460} \mathrm{~nm}\right)$ at $37^{\circ} \mathrm{C}$ of initial rate of oxidation of $6.0 \mathrm{mM}$ $o$-dianisidine $\mathrm{HCl}$ in presence of $18.0 \mathrm{mM} \mathrm{H}_{2} \mathrm{O}_{2}$ in $0.1 \mathrm{M}$ sodium acetate buffer ( $\mathrm{pH}$ 5.6) for $15 \mathrm{~min}$. Immobilized enzyme preparation was continuously agitated for entire duration of assay [5].

One unit $(1.0 \mathrm{U})$ of enzyme activity is the amount of enzyme protein that catalyzes oxidation of $1.0 \mu$ mole of $o$-dianisidine $\mathrm{HCl}$ per min at $37^{\circ} \mathrm{C}$ into colored product. An increasing concentration of enzyme (110-1000 U) was mixed to calcium alginate-pectin gel in a series of tubes. Expression of loaded enzyme was monitored by assaying the peroxidase activity.

\section{Storage stability and reusability of soluble and immobilized PGP}

Soluble and immobilized PGP were stored at $4^{\circ} \mathrm{C}$ in $50 \mathrm{mM}$ sodium acetate buffer ( $\mathrm{pH}$ 5.6) for over $50 \mathrm{~d}$. The aliquots from each preparation $(1.20 \mathrm{U})$ were taken out in triplicates at the gap of $5 \mathrm{~d}$ and were analyzed for the remaining enzyme activity. The catalytic activity measured on day 1 was considered as control (100\%) for the calculation of remaining storage activity.

Immobilized PGP was taken in triplicates for assaying peroxidase activity. After each assay the immobilized enzyme preparation was taken out, washed and stored overnight in $50 \mathrm{mM}$ sodium acetate buffer, pH 5.6 at $4^{\circ} \mathrm{C}$. The activity was assayed for ten successive days. The catalytic activity determined for the first time was considered as control $(100 \%)$ for the calculation of remaining percent activity after each use.

\section{Preparation of synthetic dye solutions and calculation of percent dye decolorization}

The synthetic solutions of disperse dyes $(25-50 \mathrm{mg} / \mathrm{mL})$ were prepared in distilled water to examine their decolorization by PGP. A mixture of disperse dyes consisting of DR19 and DB9 was prepared by mixing each dye in equal proportion of color intensity [5]. To compare various experiments, the decolorization was calculated for each dye or mixture of dyes. Dye decolorization was monitored by measuring the difference at the maximum absorbance for each dye as compared with control experiments without enzyme on UV-visible spectrophotometer (JASCO V-550, Japan). Untreated dye solution (inclusive of all reagents except the enzymes) was used as control for calculation of percent decolorization. The dye decolorization was calculated as the ratio of the difference of absorbance of treated and untreated dye to that of treated dye and converted in terms of percentage. Five independent experiments were carried out in duplicate and the mean was calculated.

\section{Decolorization of dye solution by soluble and immobilized peroxidase in batch processes}

The dye solution $(200 \mathrm{~mL})$ was treated with soluble and immobilized PGP $(27.6 \mathrm{U})$ in $100 \mathrm{mM}$ sodium acetate buffer, $\mathrm{pH} 5.6$ in the presence of $0.2 \mathrm{mM}$ riboflavin as redox mediator and $0.8 \mathrm{mM} \mathrm{H}_{2} \mathrm{O}_{2}$ for $1 \mathrm{~h}$ at $37^{\circ} \mathrm{C}$. The treated samples were centrifuged at $3000 \mathrm{x} \mathrm{g}$ for $15 \mathrm{~min}$. The residual dye concentration was measured spectrophotometrically at specific wavelength maxima of the dye. Untreated dye solution was considered as control (100\%) for the calculation of percent decolorization. 
Citation: Jamal F, Singh S, Khatoon S, Mehrotra S (2013) Application of Immobilized Pointed Gourd (Trichosanthes dioica) Peroxidase-Concanavalin A Complex on Calcium Alginate Pectin Gel in Decolorization of Synthetic Dyes Using Batch Processes and Continuous Two Reactor System. J Bioprocess Biotech 3: 131 doi: 10.4172/2155-9821.1000131

Page 3 of 5

\section{Reusability of immobilized PGP in the decolorization of disperse dye}

DR19 and mixture of dyes [DR19+DB9] were incubated with immobilized PGP for $1 \mathrm{~h}$ as mentioned earlier. The enzyme was separated by centrifugation and stored in the assay buffer for over $12 \mathrm{~h}$. Experiments was repeated upto 10 times with the same preparation of PGP and each time with a fresh batch of dye solution. Dye decolorization was monitored at specific wave length maxima of the dye solutions. The percent decolorization was calculated by taking untreated dye or mixture of dyes as control (100\%).

\section{Continuous dye decolorization using a two-reactor system}

For the continuous removal of dyes from solutions two-reactor system was developed. A column $(15 \times 2.0 \mathrm{~cm})$ was filled with $10 \mathrm{~g}$ entrapped Con A-PGP complex (1268 U) connected to second column $(15 \times 2.0 \mathrm{~cm})$ containing activated silica. Silica was activated by heating in an oven $\left(120^{\circ} \mathrm{C}\right)$ for overnight and then washed thrice with $30 \mathrm{~mL}$ distilled water. The flow rate was maintained at $6.4 \mathrm{~mL} / \mathrm{h}$ and the feed solution contained either DR19 or mixture of DR19 and DB9 in two independent reactor systems. Dye solutions were run under the same experimental conditions. Reactors were operated at room temperature $\left(37^{\circ} \mathrm{C}\right)$ for a period of 4 months. Immobilized PGP treated and activated silica gel adsorbed samples were collected at an interval of $20 \mathrm{~d}$ and the absorbance of each sample was recorded.

Procedure for the dye decolorization was followed by centrifugation and clear diluted solution was considered for total organic carbon determination. TOC was evaluated by using a TOC analyzer. Each control and treated DR19 or mixture of dyes (DR19+DB9) was diluted 10 -fold before determining their TOC content.

\section{Results and Discussion}

\section{Purification of PGP and preparation of PGP-Con A complex}

The crude extract of pointed gourd exhibited an initial specific activity of $96 \mathrm{U} / \mathrm{mg}$ of protein. Peroxidase was partially purified by ammonium sulphate precipitation and specific activity of preparation was increased 3.5 fold over crude enzyme. This enzyme preparation was used for direct immobilization as enzyme-Con A complex.

Peroxidases from $T$. dioica are usually glycosylated proteins. These enzymes in soluble states may leak out of beads over prolonged retention or repeated use. Thus to prevent the leaching of enzymes from porous gel beads, these enzyme molecules were complexed with lectin concanavalin A. The insoluble PGP-Con A complex was subsequently entrapped into calcium alginate-pectin gel. With $0.2 \mathrm{~mL}$ of Con A the PGP-Con A complex expressed an activity of 79\% which on entrapment into calcium alginate-pectin gel resulted in further decrease of peroxidase activity (Table 1).

\section{Entrapment of PGP-Con A complex in calcium alginate- pectin beads}

Immobilization by means of entrapment is a simple and effective technique. Partially purified PGP precipitated with Con A was used for direct immobilization onto calcium alginate pectin beads. Entrapped PGP-Con A peroxidase complex retained only $56 \%$ of the original activity (Table 1). Further, the effect of enzyme loading on entrapped activity was evaluated by entrapping increasing concentration of enzyme. Optimum concentration $(418 \mathrm{U} / \mathrm{mL})$ was sufficient for maximum expression of peroxidase activity by entrapped preparation.
Cross-linked enzymes or pre-immobilized enzymes that could remain inside polymeric matrices for longer duration than soluble enzymes provide higher mechanical and operational stability to enzymes $[16,20]$. It indicated that enzymes with high molecular mass could stay for longer period inside polymeric matrix. Preimmobilization increases molecular dimensioning of the enzyme and thus prevents its leaching from alginate beads.

\section{Reusability and Storage stability of immobilized PGP}

Reusability of preparation has been shown in Figure 1. After sixth repeated use, PGP-Con A retained $56.6 \%$ of the original activity whereas entrapped exhibited $71.1 \%$ peroxidase activity. However, thereafter progressive decline in activity was recorded and on day 10 PGP-Con A complex and entrapped PGP-Con A complex retained only $19.6 \%$ and $38.7 \%$ activity respectively.

Enzyme reuse provides a number of cost effective advantages that are often an essential prerequisite for establishing an economically viable enzyme catalyzed process [9]. Immobilized PGP (entrapped PGP-Con A complex) retained 53.6\% of its original activity even after its ninth successive uses (Figure 1). PGP-Con A complex exhibited loss in enzymatic activity after sixth repeated use as compared to entrapped PGP. The loss in activity upon reusability may be due to several factors, one of which could be due to inhibition of enzyme by its reaction product [21]. Another factor causing profound loss in activity of PGPCon A complex could be the loss in recovery while monitoring its reusability.

Storage stability of soluble and immobilized preparations of PGP was monitored at a gap of $5 \mathrm{~d}$ for $50 \mathrm{~d}$ at $4^{\circ} \mathrm{C}$ (Figure 2). The immobilized peroxidase preparation [entrapped PGP-Con A complex] retained $59.6 \%$ of the original activity after a period of $50 \mathrm{~d}$. The PGP-Con A complex exhibited $43.5 \%$ peroxidase activity and on the contrary the soluble form of PGP lost upto $84.7 \%$ activity under similar storage conditions. Thus, immobilized PGP exhibited remarkable stability on prolonged storage. On the basis of results obtained in the present work, it can be concluded that the stability offered by immobilized

\begin{tabular}{|l|c|c|}
\hline \multicolumn{1}{|c|}{ Type of Immobilization } & Original Activity* & Expressed Activity $^{*}$ \\
\hline PGP-Con A Complex & $100 \%$ & $79 \%$ \\
\hline $\begin{array}{l}\text { PGP-Con A complex } \\
\text { entrapped on calcium-alginate } \\
\text { pectin gel }\end{array}$ & $100 \%$ & $56 \%$ \\
\hline
\end{tabular}

*Original activity is the activity of soluble PGP and the expressed activity is the activity achieved after immobilization.

Table 1: Activities of PGP immobilized with lectin Con A and calcium-alginate pectin gel.

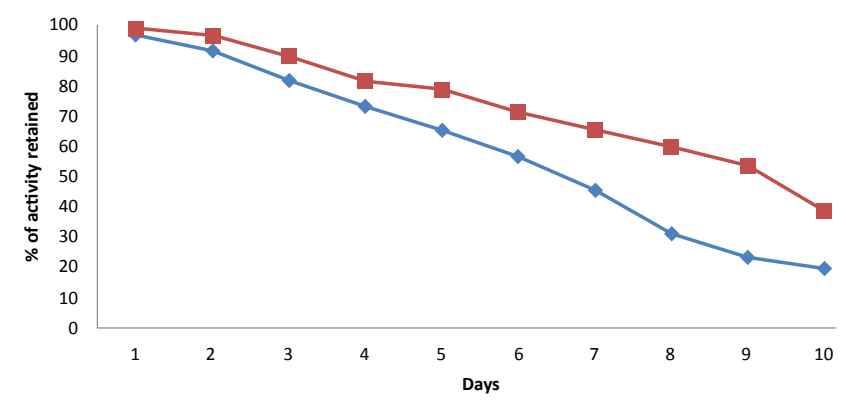

-PGP-Con A complex -P-PGP-Con A complex entrapped on calcium-alginate pectin gel Figure 1: Reusability of immobilized preparations of PGP. 

A Complex on Calcium Alginate Pectin Gel in Decolorization of Synthetic Dyes Using Batch Processes and Continuous Two Reactor System. J Bioprocess Biotech 3: 131 doi: 10.4172/2155-9821.1000131

Page 4 of 5

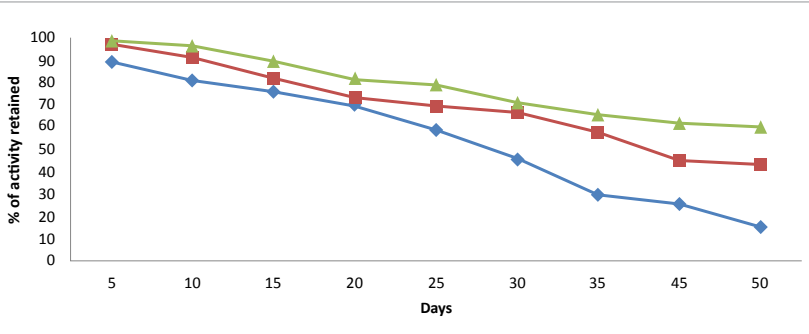

Figure 2: Storage stability of soluble and immobilized PGP.

PGP preparation could successfully be employed in reactors for the treatment of effluents containing phenolic and other aromatic pollutants including dyes which are primarily represented in textile effluents. The reusability and storage experiments further supported that the use of such a cheaper source of enzyme and support will definitely minimize the cost of immobilization and provide a suitable approach for the treatment of huge volumes of wastewater in batch processes as well as in continuous reactors.

\section{Reusability of immobilized PGP in dye decolorization}

In order to make immobilized PGP (entrapped PGP-Con A complex) use more practical in a reactor, it was necessary to investigate its reusability on repeated use in the decolorization of disperse dyes. The dye decolorizing reusability of entrapped Con A-PGP complex continuously decreased upto its tenth repeated use (Table 2). Immobilized PGP retained 51.4\% and 35.6\% for DR19 and dye mixture [DR19+DB9] respectively, after tenth repeated use.

\section{Dye decolorization by immobilized PGP in batch process and a two-reactor system}

The decolorization of dyes by PGP has been illustrated in Table 3. Soluble PGP decolorized $81.9 \%$ and $59.1 \%$ of DR19 and mixture of dyes after $2 \mathrm{~h}$ of incubation, respectively. However, immobilized PGP was more effective as compared to its soluble counterpart in the decolorization of both DR19 and mixture of dyes. Decolorization by immobilized PGP under similar conditions was $78.4 \%$ and $69.5 \%$ for DR19 and dye mixture respectively after $1 \mathrm{~h}$ of incubation. On the contrary the performance of the two-reactor system in terms of dye decolorization is shown in Table 4. Entrapped Con A-PGP complex decolorized $91.2 \%$ and $82.1 \%$ of the initial color from DR19 and dye mixture [DR19+DB9] after $20 \mathrm{~d}$, respectively. Considerable color removal from DR19 (59.4\%) and mixture of disperse dyes (53.2\%) was found even after $120 \mathrm{~d}$ and $80 \mathrm{~d}$ respectively of operation of the tworeactor system.

The treatment of DR19 and mixture of dyes [DR19+DB9] by passing through a double reactor system provided almost the water free from dyes. The dyes treated by immobilized PGP present in the first column, got adsorbed in the second column, which contained activated silica. Both the reactors worked for more than $120 \mathrm{~d}$ approximately, thus explaining their efficiency towards dye decolorization. A significant loss of color appeared when DR19 or mixture of dyes was treated with entrapped PGP-Con A complex in the presence of redox mediator, riboflavin in a continuous reactor system (Table 4). It has earlier been reported that the disappearance of peak in visible region was either due to the breakdown of chromophoric groups present in dyes or the removal of pollutants in the form of insoluble products [22].
The level of TOC in case of continuous reactors was significantly decreased in the presence of immobilized PGP treated polluted water. However, the PGP treated dye solutions exhibited great loss of TOC from the wastewater (Table 4), which suggested that the major toxic compounds could have been removed out of the treated samples. Immobilized HRP removed $88 \%$ of TOC from model wastewater containing mixture of chlorophenols [15]. It has been reported that a significant amount of TOC from polluted water containing dyes/dyemixtures and dyeing effluent was removed when treated with soluble and immobilized bitter gourd peroxidase [23]. These evidences strongly proved that immobilized PGP-Con A complex could be successfully used for the removal of dye effluents loaded with recalcitrant synthetic dyes.

\section{Conclusions}

The stability exhibited by calcium alginate-pectin entrapped Con A-PGP preparation was significantly higher compared to soluble PGP and Con A-PGP complex. Thus, immobilized PGP preparations could be exploited for developing bioreactors for the treatment of phenolic and other aromatic pollutants including synthetic dyes present in industrial effluents. A two-reactor system with simple operational protocol for decolorization/degradation of disperse dyes has been focused for the

\begin{tabular}{|c|c|c|}
\hline No of Uses & DR19 $(\mathbf{\lambda} 495 \mathrm{~nm})$ & $\begin{array}{c}\text { DR19 and DB9 mixture } \\
(\mathbf{\lambda 4 6 0 n m )}\end{array}$ \\
\cline { 2 - 3 } & $\begin{array}{c}\text { Percent Dye } \\
\text { decolorization }\end{array}$ & $\begin{array}{c}\text { Percent Dye } \\
\text { decolorization }\end{array}$ \\
\hline 1 & 93.7 & 88.2 \\
\hline 2 & 89.4 & 84.6 \\
\hline 3 & 78.6 & 74.7 \\
\hline 4 & 72.8 & 69.4 \\
\hline 5 & 67.9 & 63.5 \\
\hline 6 & 65.6 & 60.4 \\
\hline 7 & 63.9 & 51.4 \\
\hline 8 & 57.4 & 43.2 \\
\hline 10 & 53.6 & 38.5 \\
\hline
\end{tabular}

Table 2: Dye/dyes mixture decolorization and reusability of immobilized PGP. Immobilized PGP was independently incubated with DR19 and mixture of dyes [DR19+DB9] $(300 \mathrm{~mL})$ for $2 \mathrm{~h}$ at $40^{\circ} \mathrm{C}$. Dye decolorization was determined after incubation period of $2 \mathrm{~h}$. The immobilized enzyme was collected by centrifugation and stored in assay buffer at $4^{\circ} \mathrm{C}$ overnight. Next day, the similar experiment was repeated. This procedure was repeated 10 times. Each value represents the mean for three independent experiments performed in duplicate.

\begin{tabular}{|c|c|c|c|c|}
\hline \multirow{3}{*}{$\begin{array}{l}\text { Time } \\
(\min )\end{array}$} & \multicolumn{4}{|c|}{ Percent Dye decolorization } \\
\hline & \multicolumn{2}{|c|}{ DR19(入495nm) } & \multicolumn{2}{|c|}{$\begin{array}{c}\text { DR19 and DB9 mixture } \\
(\wedge 460 \mathrm{~nm})\end{array}$} \\
\hline & Soluble PGP & $\begin{array}{l}\text { Entrapped PGP. } \\
\text { Con A complex }\end{array}$ & Soluble PGP & $\begin{array}{c}\text { Entrapped } \\
\text { PGP-Con A } \\
\text { complex }\end{array}$ \\
\hline 20 & 69.8 & 78.5 & 61.2 & 69.5 \\
\hline 40 & 74.6 & 78.5 & 60.7 & 69.6 \\
\hline 60 & 78.8 & 78.4 & 60.4 & 69.5 \\
\hline 80 & 79.9 & 78.4 & 59.5 & 69.5 \\
\hline 100 & 79.9 & 78.4 & 59.4 & 69.4 \\
\hline 120 & 81.9 & 78.4 & 59.1 & 69.4 \\
\hline 140 & 62.4 & 78.4 & 38.2 & 69.3 \\
\hline 160 & 59.6 & 78.4 & 28.5 & 69.4 \\
\hline 180 & 42.2 & 78.4 & 25.6 & 69.4 \\
\hline
\end{tabular}

Table 3: Dye decolorization in batch processes. DR19 or mixture of dyes [DR19+DB9] $(250 \mathrm{~mL})$ was treated with soluble and immobilized PGP (27.6 U) for varying times in batch processes. Each value represents the mean for five independent experiments performed in duplicate. 
Citation: Jamal F, Singh S, Khatoon S, Mehrotra S (2013) Application of Immobilized Pointed Gourd (Trichosanthes dioica) Peroxidase-Concanavalin A Complex on Calcium Alginate Pectin Gel in Decolorization of Synthetic Dyes Using Batch Processes and Continuous Two Reactor System. J Bioprocess Biotech 3: 131 doi: 10.4172/2155-9821.1000131

\begin{tabular}{|c|c|c|c|c|}
\hline \multirow[b]{2}{*}{$\begin{array}{l}\text { No of } \\
\text { days }\end{array}$} & \multicolumn{2}{|c|}{ DR19 (入495nm) } & \multicolumn{2}{|c|}{$\begin{array}{c}\text { Mixture of DR19 and DB9 } \\
(\lambda 460 \mathrm{~nm})\end{array}$} \\
\hline & $\begin{array}{c}\text { Percent Dye } \\
\text { decolorization }\end{array}$ & $\begin{array}{l}\text { Percent } \\
\text { TOC } \\
\text { Removal }\end{array}$ & $\begin{array}{l}\text { Percent Dye } \\
\text { decolorization }\end{array}$ & $\begin{array}{l}\text { Percent TOC } \\
\text { Removal }\end{array}$ \\
\hline 20 & 91.2 & 93.2 & 82.1 & 83.4 \\
\hline 40 & 79.4 & 80.1 & 76.9 & 77.3 \\
\hline 60 & 77.7 & 78.2 & 64.3 & 67.8 \\
\hline 80 & 65.8 & 66.7 & 53.2 & 56.3 \\
\hline 100 & 63.4 & 62.8 & 33.7 & 37.4 \\
\hline 120 & 59.4 & 60.2 & 23.2 & 25.1 \\
\hline
\end{tabular}

Table 4: Continuous removal of color and TOC from DR19 and a mixture of [DR19+DB9] by immobilized PGP in a two-reactor system. DR19/ mixture of dyes was treated with PGP in a two-reactor system as described in text. Each value represents the mean for five independent experiments performed in duplicate.

potential future use of immobilized peroxidases. Interestingly, the described system is developed with a cheaper biocatalyst that is quite effective in treating dyes continuously in a small laboratory reactor.

\section{Future directions}

With the recent focus on enzyme based treatment of colored wastewater/ industrial textile effluent, the enzymes in soluble form cannot be exploited on large scale due to their limitations of stability and reusability. Consequently, the use of immobilized enzymes has significant advantages over soluble enzymes. In the near future, cost effective, eco-friendly technologies based on the enzymatic approach for treatment of dyes present in the industrial effluents/wastewater will play a vital role. Comprehensive studies on the chemical modification of pointed gourd peroxidase would provide us lead to exploit novel versions of peroxidases and thereby increase their resistance to withstand high concentrations of phenolic compounds/ dyes in effluent wastewater. Thus, our aim would be to characterize and express putative peroxidase from Trichosanthes dioica (Pointed Gourd) whose peroxidase activity has recently been shown by us to effectively decolorize several recalcitrant synthetic dyes as well as non textile dyes. This would go a long way in expressing an effective version of peroxidase gene and subsequently use its products in bioreactors to treat textile effluents. Such peroxidase system would retain high remaining activity in a recycle processing unit deploying immobilized enzyme.

\section{Acknowledgement}

We are thankful to the Department of Science and Technology (DST-FIST) under the Ministry of Science and Technology for providing financial assistance towards infrastructure development for carrying out this work. Grant received from CSTUP, Lucknow is gratefully acknowledged.

\section{References}

1. Azevedo AM, Martins VC, Prazeres DM, VojinoviÄ $\ddagger$ V, Cabral JM, et al. (2003) Horseradish peroxidase: a valuable tool in biotechnology. Biotechnol Annu Rev 9: 199-247.

2. Chanwun T, Muhamad N, Chirapongsatonkul N, Churngchow N (2013) Hevea brasiliensis cell suspension peroxidase: purification, characterization and application for dye decolorization. AMB Express 3: 14.

3. Husain Q (2006) Potential applications of the oxidoreductive enzymes in the decolorization and detoxification of textile and other synthetic dyes from polluted water: a review. Crit Rev Biotechnol 26: 201-221.

4. Jamal F, Pandey PK, Qidwai T (2010) Potential of peroxidase enzyme from Trichosanthes dioica to mediate disperse dye decolorization in conjunction with redox mediators. J Mol Cat B: Enzym 66: 177-181.
5. Jamal F, Qidwai T, Pandey PK, Singh R, Singh S (2011) Azo and anthraquinone dye decolorization in relation to its molecular structure using soluble Trichosanthes dioica peroxidase supplemented with redox mediator. Catal Commun 12: 1218-1223.

6. López C, Mielgo I, Moreira MT, Feijoo G, Lema JM (2002) Enzymatic membrane reactors for biodegradation of recalcitrant compounds. Application to dye decolourisation. J Biotechnol 99: 249-257.

7. Jamal F, Qidwai T, Singh D, Pandey PK (2012) Biocatalytic activity of immobilized pointed gourd (Trichosanthes dioica) peroxidase-concanavalin A complex on calcium alginate pectin gel. J Mol Cat B: Enzy 74: 125-131.

8. Silva MC, Correa AD, Amorim MTSP, Parpot P, Torres JA, et al. (2012) Decolorization of the phthalocyanine dye reactive blue 21 by turnip peroxidase and assessment of its oxidation products. J Mol Cat B: Enzym 77: 9-14.

9. Zille A, Tzanov T, Gübitz GM, Cavaco-Paulo A (2003) Immobilized laccase for decolourization of Reactive Black 5 dyeing effluent. Biotechnol Lett 25: 14731477.

10. Gholami-Borujeni F, Mahvi AH, Naseri S, Faramarzi MA, Nabizadeh R, et al. (2011) Application of immobilized horseradish peroxidase for removal and detoxification of azo dye from aqueous solution. Res J Chem Environ 15, 217 222.

11. Akhtar S, Khan AA, Husain Q (2005) Simultaneous purification and immobilization of bitter gourd (Momordica charantia) peroxidases on bioaffinity support. J Chem Technol Biotechnol 80: 198-205.

12. Gupta MN, Mattiasson B (1992) Unique applications of immobilized proteins in bioanalytical systems. Methods Biochem Anal 36: 1-34

13. Mislovicová D, Gemeiner P, Sandula J, Masárová J, Vikartovská A, et al (2000) Examination of bioaffinity immobilization by precipitation of mannan and mannan-containing enzymes with legume lectins. Biotechnol Appl Biochem 31 : 153-159.

14. Gomez JL, Bodalo A, Gomez E, Bastida J, Hidalgo AM, et al. (2006) Immobilization of peroxidases on glass beads: An improved alternative for phenol removal. Enz Microb Technol 39: 1016-1022.

15. Husain M, Husain Q (2007) Applications of Redox Mediators in the Treatment of Organic Pollutants by Using Oxidoreductive Enzymes. Crit Rev Environ Sci Technol 38: 1-42

16. Betancor L, López-Gallego F, Hidalgo A, Fuentes M, Podrasky O, et al. (2005) Advantages of the pre-immobilization of enzymes on porous supports for their entrapment in sol-gels. Biomacromolecules 6: 1027-1030.

17. Kulshrestha $Y$, Husain Q (2006) Direct immobilization of peroxidase on DEAE cellulose from ammonium sulphate fractionated proteins of bitter gourd (Momordica charantia). Enz Microb Technol 38: 470-477.

18. Lowry OH, Rosebrough NJ, Farr AL, Randall RJ (1951) Protein measurement with the Folin phenol reagent. J Biol Chem 193: 265-275

19. Nigma SC, Tsao I-F, Sakoda A, Wang HY (1988) Techniques for preparing hydrogel membrane capsule. Biotechnol Techn 2: 271-276.

20. Musthapa SM, Akhtar S, Khan AA, Husain Q (2004) An economical, simple and high yield procedure for the immobilization/stabilization of peroxidases from turnip roots. J Sci Ind Res 63: 540-547.

21. Gåserød O, Sannes A, Skjåk-Braek G (1999) Microcapsules of alginatechitosan. II. A study of capsule stability and permeability. Biomaterials 20: 773783.

22. Moreira MT, Palma C, Mielgo I, Feijoo G, Lema JM (2001) In vitro degradation of a polymeric dye (Poly R-478) by manganese peroxidase. Biotechnol Bioeng 75: 362-368.

23. Akhtar S, Husain Q (2006) Potential applications of immobilized bitter gourd (Momordica charantia) peroxidase in the removal of phenols from polluted water. Chemosphere 65: 1228-1235. 